\title{
NOTES ON THE OCCURRENCE AND GENDER-BASED MORPHOLOGICAL ASPECTS OF POTAMOTRYGON MOTOROCELASMOBRANCHII: POTAMOTRYGONIDAE] IN THE COMPLEX OF THE VIANA LAKE SYSTEM- MARANHÃO, BRAZIL
}

\author{
NOTAS SOBRE A OCORRÊNCIA E ASPECTOS MORFOLÓGICOS GÊNERO-DEPENDENTES EM POTAMOTRYGON \\ MOTORO CELASMOBRANCHII: POTAMOTRYGONIDAEJ NO COMPLEXO DO SISTEMA LACUSTRE DE VIANA - \\ MARANHÃO, BRASIL
}

\section{NOTAS SOBRE LA OCURRENCIA Y ASPECTOS MORFOLÓGICOS BASADOS EN EL GÉNERO DE POTAMOTRYGON MOTORO CELASMOBRANCHII: POTAMOTRYGONIDAE] EN EL COMPLEJO DEL SISTEMA DEL LAGO VIANA - MARANHÃO, BRASIL}

\begin{abstract}
The Brazilian Amazonian coast, extending from Amapá to Maranhão states, is drained by a series of small to medium sized rivers of the Amazon basin. The PindaréMearim is an isolated basin formed by the junction of the Pindaré and Mearim rivers at its lower portion. Along the Pindaré and Mearim rivers there is a single reported species of freshwater stingray identified as Potamotrygon motoro. Although specimens have been deposited in research institutions, most of these specimens have been captured on the Amazon basin and its direct tributaries or along the Panará-Paraguay river basin. Hence, there is a severe lack of information on the $P$. motoro of the Pindaré- Mearim river basin. Here we present new data regarding $P$. motoro general morphology, emphasizing the color variation, sexual dimorphism and notes on its biological aspects.
\end{abstract}

Getulio Rincon'

Kerly C. M. Pereira Carlos Eduardo S. Santos

Natascha Wosnick ${ }^{2}$

Ana Rita O. P. Nunes

Renata D. Leite ${ }^{2}$

Ynês A. Araújo ${ }^{1}$

Isa P. Silva

André Augusto G. Silva

Jorge Luiz S. Nunes ${ }^{3}$

\footnotetext{
1 Universidade Federal do Maranhão-UFMA, Curso de Engenharia de Pesca. Estrada Pinheiro Pacas, km 10, s/n. Pinheiro, Maranhão. CEP-65.200-ooo.

2 Universidade Federal do Paraná-UFPR, Departamento de Zoologia, Programa de Pós-Graduação em Zoologia. Centro Politécnico. CEP 81.531-990, Curitiba-PR.

3 Universidade Federal do Maranhão-UFMA, Departamento de Oceanografia e Limnologia, Laboratório de Organismos Aquáticos. Campus Bacanga. CEP 65080-805, São Luís-MA.
} 
Keywords: freshwater; elasmobranch; ocellate river stingray; morphology.

\section{Resumo}

A costa amazônica brasileira, que se estende desde o estado do Amapá até o Maranhão, é drenada por uma série de rios de pequeno e médio porte na bacia do Rio Amazonas. A bacia do rio Pindaré-Mearim é isolada, formada pela união dos rios Pindaré e Mearim em sua porção inferior. Ao longo dessa bacia, há somente uma espécie de raia de água doce, Potamotrygon motoro. Apesar de exemplares dessa espécie terem sido depositados em instituições de pesquisa, a maioria destes foi capturada na bacia do Amazonas e seus afluentes diretos ou ao longo da bacia Paraná-Paraguai. Desta forma, há uma grave falta de informações sobre $P$. motoro da bacia do Pindaré-Mearim. Aqui apresentamos novos dados sobre a morfologia geral de $P$. motoro enfatizando a variação de colorido, dimorfismo sexual e notas sobre aspectos de sua biologia.

Palavras-chave: água doce; elasmobrânquio; raia-de-fogo; morfologia.

\section{Resúmen}

La costa amazónica brasileña, que se extiende desde el estado de Amapá hasta Maranhão, es drenada por una serie de ríos de pequeño a mediano porte en la cuenca del río Amazonas. Pindaré-Mearim es una cuenca aislada, formada por la unión de los ríos Pindaré y Mearim en su porción inferior. A lo largo de la cuenca, hay solamente una especie de raya de agua dulce, Potamotrygon motoro. Aunque los especímenes de esta especie se depositaron en instituciones de investigación, la mayoría fue capturada en la cuenca del Amazonas y sus afluentes directos o a lo largo de la cuenca del río Panará-Paraguay. Por lo tanto, hay una gran falta de información sobre $P$. motoro en la cuenca del río Pindaré-Mearim. En el presente trabajo son presentados nuevos datos sobre la morfología general de la especie, enfatizando la variación del color, el dimorfismo sexual y una nota sobre sus aspectos biológicos.

Palabras clave: agua dulce; elasmobranquio; raya ocelada de río; morfología.

\section{INTRODUCTION}

The freshwater stingrays of the Potamotrygonidae family (Chondrichthyes: Elasmobranchii) comprise five genera, Potamotrygon Garman 1877, Heliotrygon Carvalho and Lovejoy 2011, Paratrygon Duméril 1865, Plesiotrygon Rosa Castello and Thorson, 1987 and the recently included and revised amphi-American Styracura Carvalho, Loboda and Silva 2016 (Carvalho 2016), formerly identified as Himantura Müller and Henle 1837. The family includes 42 valid species distributed in five genera, Potamotrygon (35), Heliotrygon (2), Paratrygon (1), Plesiotrygon (1) and Styracura (2) (Silva and Loboda 2019). The only properly marine and estuarine representatives are Styracura schmardae (Werner 1904) and S. pacifica (Beebe and Tee-Van 1941) 
(Bigelow and Schroeder 1951; Castro-Aguirre 1978; Thorson et al. 1983; Cervigón et al. 1992; Almeida et al. 2008), although some species have been observed in brackish waters such as P. scobina Garman 1913 and P. orbignyi (Castelnau 1855) in the Amazon estuary along with marine species (Charvet-Almeida 2001; Almeida 2003).

The Amazonian coast of Brazil, extending from Amapá to Maranhão states, is drained by a series of small to medium sized rivers of the Amazon basin (Geyer et al. 1996; Pereira et al. 2012); not all directly linked to the Amazon flow system (drainage), but also under the influence of its mixing coastal waters (Nittrouer and DeMaster 1996). The Pindaré-Mearim basin is an isolated basin formed by the junction of the Pindaré and Mearim rivers at its lower portion, which drains to the São Marcos Bay located $480 \mathrm{~km}$ southeast from the Amazon mouth. Along the lower Pindaré, just before the junction with the Mearim river, there are a series of shallow lakes formed by the extension of the plains, a repeated process in the region known as "Baixada Maranhense", and still under the influence of the high tides (up to seven meters) in the São Marcos Bay. This influence is remarkable and reported by local fishermen on the life cycle of marine shrimps and crabs occurring in the lakes and occasional captures of sharks and sawfishes (Feitosa et al. 2016; Feitosa et al. 2017; Feitosa et al. 2018). Most of the species reported in the Mearim basin are Amazonian with some interesting exclusions and endemism cases (Piorski et al. 2017; Abreu et al. 2019). Along the Pindaré and Mearim rivers there is one single reported species of freshwater stingray identified as Potamotrygon motoro (Müller and Henle 1841) by Compagno and Cook (1995), Soares (2005) and posteriorly confirmed based on a broad recent review for the species ( $q$. v. Loboda and Carvalho 2013; Carvalho et al. 2016). Although specimens of $P$. motoro have been deposited in research institutions in Brazil and several other foreign countries, most of these specimens were captured on the Amazon basin and its direct tributaries or along the Panará-Paraguay river basin. Hence, there is a severe lack of information on the $P$. motoro of the PindaréMearim river basin and availability of specimens for scientific analysis in a number of representative collections.

Here we present a report of the $P$. motoro in the Viana lagoon system based on a larger sample size, emphasizing the color variation, sexual dimorphism and notes on its biological aspects.

\section{MATERIAL AND METHODS}

All specimens were captured in the Viana Lake (Maranhão State, Brazil), part of the lower Pindaré-Mearim river basin ( $3^{\circ} 13^{\prime} 59^{\prime \prime S}$ e $44^{\circ} 59^{\prime} 13^{\prime \prime} \mathrm{W}$ ) (Figure $1)$, by bottom longline and baited with local small fishes. The catches were in the night period from 6 p.m to 2 a.m. in order to avoid piranhas (Pygocentrus sp and Serrasalmus sp.) predation over the baits or captured stingrays. Five cruises were performed (July/o2/2017 one single gravid female; September/30/2017, 26 specimens; 
July/10/2018, 5 specimens; November/16/2018, 7 specimens; and July/16/2019, 4 specimens) (Figure 1). Immediately after capture all specimens were conditioned in ice and transported to the laboratory where they were frozen waiting for analysis. When defrosted, they were measured to the nearest millimeter with Vernier calipers, weighed to the nearest gram (g) for total and gutted weight (Toledo scale) and to the centesimal of gram for internal organs (Mars scale), dissected for reproductive, feeding and taxonomic studies, and preserved in formalin solution (10\%).
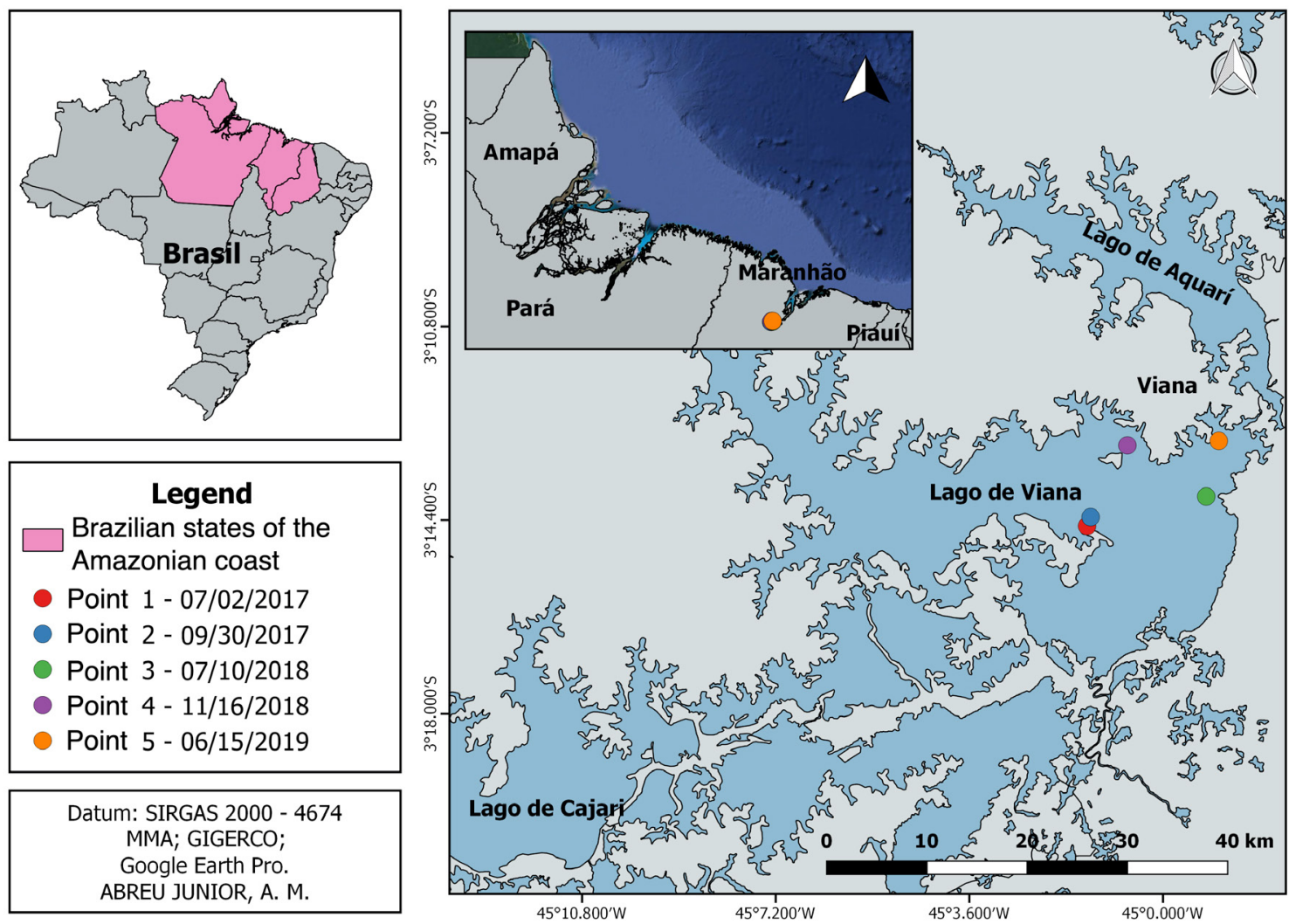

Figure 1. Viana Lake in the Pindaré-Mearim river basin. The colored dots represent the sample sites: Site 1. $3^{\circ} 14^{\prime} 32 » \mathrm{~S}-45^{\circ} 01^{\prime} 26^{\prime \prime} \mathrm{W}$ (July/o2/2017); Site 2. $3^{\circ} 14^{\prime} 22 » \mathrm{~S}-45^{\circ} 01^{\prime} 22^{\prime \prime} \mathrm{W}$ (September/30/2017); Site 3. 3 ${ }^{\circ} 13^{\prime} 59^{\prime \prime S}-44^{\circ} 59^{\prime} 13^{\prime \prime W}$ (July/10/2018), Site 4. $3^{\circ} 13^{\prime} 02^{\prime \prime S}-45^{\circ} 00^{\prime} 41^{\prime \prime W}$ (November/16/2018), and Site 5. $3^{\circ} 12$ '57"S-44 ${ }^{\circ} 8^{\prime} 59^{\prime \prime} \mathrm{W}$ (June/15/2019).

All measurements followed Rosa (1985) (Figure 2) modified on the inclusion of the following measurements: disc width at the eyes (transverse disc line passing over the anterior margin of the eyes), disc width at the origin of the pelvic fins, snout to 1st gill slit, mouth to 1st gill slit, cloacal opening length, pelvic fin base, tail length from posterior disc margin to sting insertion, inner clasper length, dorsal tail length and prepelvic length. Tooth and spinulation morphology followed Deynat and Séret (1996). 

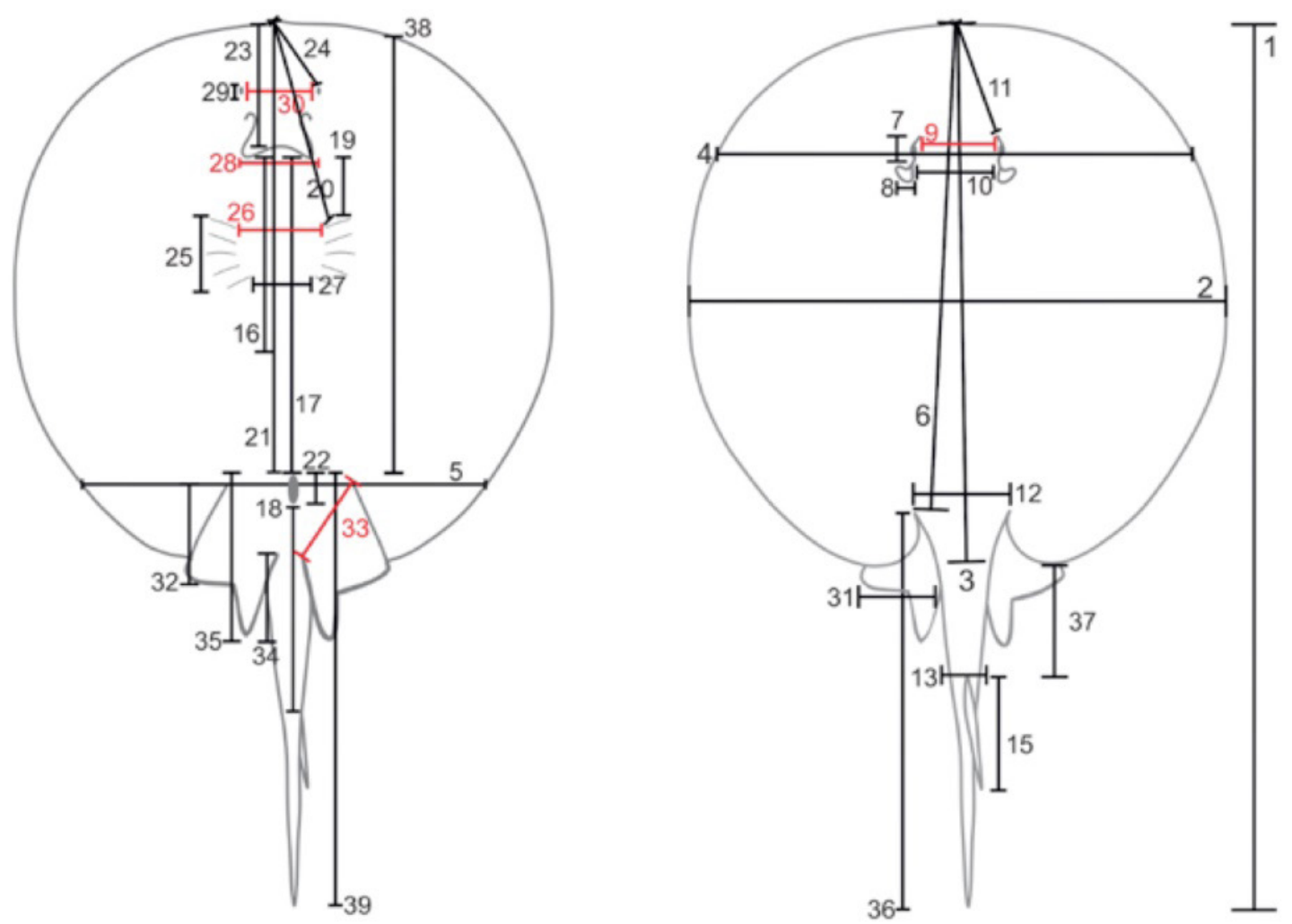

Figure 2. Measurements taken from analyzed specimens of $P$. motoro; 1. Total length (TL), 2. Disc width (DW), 3. Disc length (DL), 4. Disc width at the eyes (DWE), 5. Disc width at the origin of the pelvic fins (DWP), 6. Internal disc length (IDL), 7. Eye length

(EL), 8. Spiracle length (ESL), 9. Interocular width (IOW), 10. Interspiracular width (ISW), 11. Preocular length (PL), 12. Tail width (TW), 13. Tail width at sting (TWS), 14. Tail heigh (TH), 15. Sting length (SL), 16. Prescapulocoracoid length (PSL), 17. Precloacal length (PCL), 18. Cloaca to caudal sting (CCS), 19. Mouth to first branchial slit (MBS), 20. Prebranchial length (PBL), 21. Mouth to cloaca (MC), 22. Cloacal length (CL), 23. Preoral length (POL), 24. Prenarial length (PNL), 25. Branchial basket length (BBL), 26. Branchial basket width (BBW), 27. Branchial basket width at fifth slit (BBW5), 28. Mouth width (MW), 29. Nostril length (NL), 30. Internarial width (INW), 31. Pelvic fin width (PW), 32. Pelvic fin length (PFL), 33. Pelvic fin base (PFB), 34. Inner clasper length (ICL), 35. Clasper length (CL), 36. Dorsal tail length (DTL), 37. Tail length from posterior disc margin to sting insertion (TLS), 38. Prepelvic length (PCL), 39. Tail length (TL).

All specimens were labeled and saved in tanks of formalin solution and partially deposited in the UFMA-Pinheiro collection of fishes. Three specimens were deposited at the Universidade Federal do Maranhão Fish Collection (CPUFMA-3161, three male specimens with $180 \mathrm{~mm}, 290 \mathrm{~mm}$ and $350 \mathrm{~mm} \mathrm{DW}$, captured in the same cruise, September/30/2017). This study followed the license for permanent collecting of zoological material of the Instituto Chico Mendes de Conservação da Biodiversidade-ICMBio (SISBio number 58240-1) and was submitted to the Ethics 
Commission on the Use of Animals of the Universidade Federal do Maranhão-UFMA (Certificate CIAEP: 01.0341.2014).

Statistical analyses were performed on the index data matrices obtained from the morphometric protocol measurements for each specimen. In order to avoid the effect of allometry, each morphometric measurement was transformed into morphological indices calculated as a percentage of disc width (DW). Data were previously tested for their nature for normality (Shapiro-Wilk test) and homogeneity (Levene test). The Student's t-test was applied to the matrix to test morphometric differences between genders, but when the data did not meet the prerogatives to apply parametric tests, the Wilcoxon test was chosen. The analyses were performed in the $\mathrm{R}$ environment ( $\mathrm{R}$ Development Core Team 2011). In order to evaluate the ontogenetic variation between genders, the allometry coefficient was calculated based on the power equation $\mathrm{Y}=\mathrm{aXb}$. This equation was linearized as $\log \mathrm{y}=\log \mathrm{a}$ $+\mathrm{b} \log \mathrm{x}$, and LD was used as the predictor variable $(\mathrm{x})$, and the other dimensions as the independent variable (y). For this analysis we used the program REGRANS (Pezzuto, 1993). All tests considered the significance level of $5 \%$.

\section{RESULTS}

\section{Species Identification}

The sample consisted of 27 females with disc widths (DW) ranging from 137 to $613 \mathrm{~mm}$, and 16 males with disc widths from 132 to $447 \mathrm{~mm}$ DW. All fortythree specimens presented an expected color variation within the same species and, according to local fishermen, this is the only stingray color pattern they know to occur in freshwater stingrays in the Viana Lake. These are evidences that there is only one species in the area. Based on the key for species of the genus Potamotrygon provided by Rosa and Carvalho (2016) and review of Carvalho (2016), all specimens were putatively identified as Potamotrygon motoro by the presence of circular ocelli larger than the eye diameter and distributed in concentric pattern, no ocelli over the tail, spines on the tail in a single longitudinal line and the presence of star-shaped dermal denticles over the dorsal disc.

\section{General Morphology}

Stingrays with oval shaped disc, slightly longer than broad; pelvic fins ventrally to the pectorals, extending their posterior margins immediately behind the pectorals; tail dorsally origin at the level of cloaca, slightly depressed at the caudal sting origin to well compressed at the sting ending, covered with a single dorsal line of posteriorly curved spines that extend to the sting base; irregular accessory spines 
may occur; lateral spines smaller and randomly distributed. Pelvic fins are broad, strong and ventrally positioned slightly forward to the tail origin; anterior margin straight in juveniles, but slightly convex in larger specimens; broadly rounded apex and fringed posterior margins.

Teeth in quincunx along the jaws with distinct sexual dimorphism, monognathic and dignathic heterodonty. Upper jaw arranged in three distinct regions for both sexes, central, intermediate and posterior, but far more evident (aberrant) in females; females with rhomboid molariform teeth on central rows, changing abruptly in size and form to hexagonal on intermediate rows and changing again to rhomboid teeth on posterior rows; males with teeth crowns lanceolate and single cusped on central rows, changing abruptly in form (hexagonal) and size on intermediate rows and returning to rhomboid on posterior teeth rows (Figure 3). Lower jaw with more uniform molariform teeth in females, but in males' central rows are single cusped while lateral and posterior teeth are rhomboid molariformes. Immature specimens with uniform molariform teeth and no evident dimorphism or heterodonty.

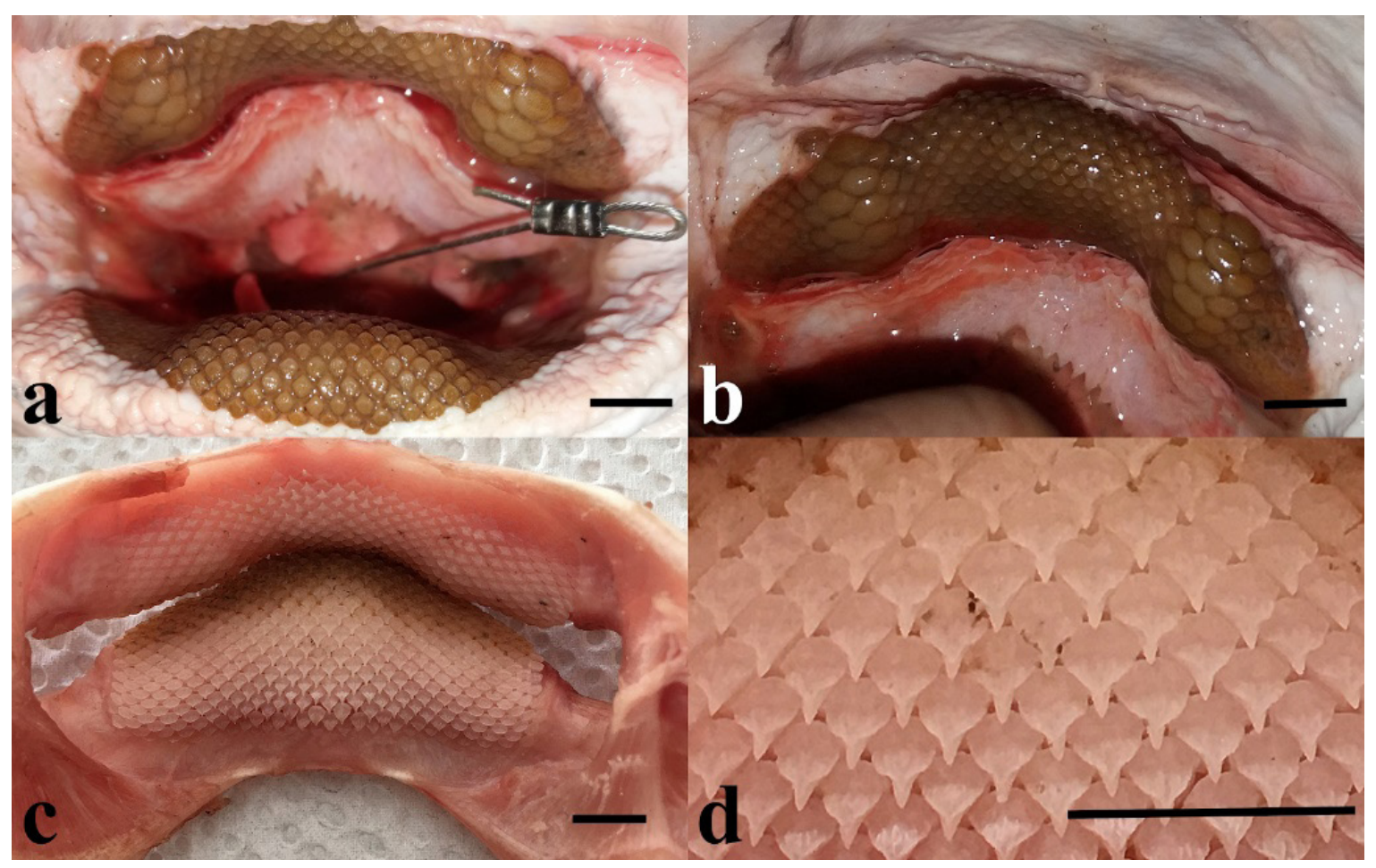

Figure 3. Variation in tooth morphology in adult female (a, b) and adult male (c, d) in $P$. motoro of the Viana Lake. Scale bar represents $5 \mathrm{~mm}$. 


\section{Spinulation}

Dorsal surface of the disc covered with star-shaped dermal denticles distributed mostly uniformly, but with enlarging denticles from disc border toward the central area. The borders of the disc and spiracle-eye regions are covered with smaller and multicuspidate denticles replacing abruptly to the star-shaped dermal denticles type. Median line of spines extending from the origin of the tail, in some specimens slightly anterior, to the sting base; frequently one single line of posteriorly recurved spines with occasional two irregular lines. Smaller dorso-laterally spines on the tail occur as transitional enlargement of denticles, randomly distributed and pointed upward (Figure 4).

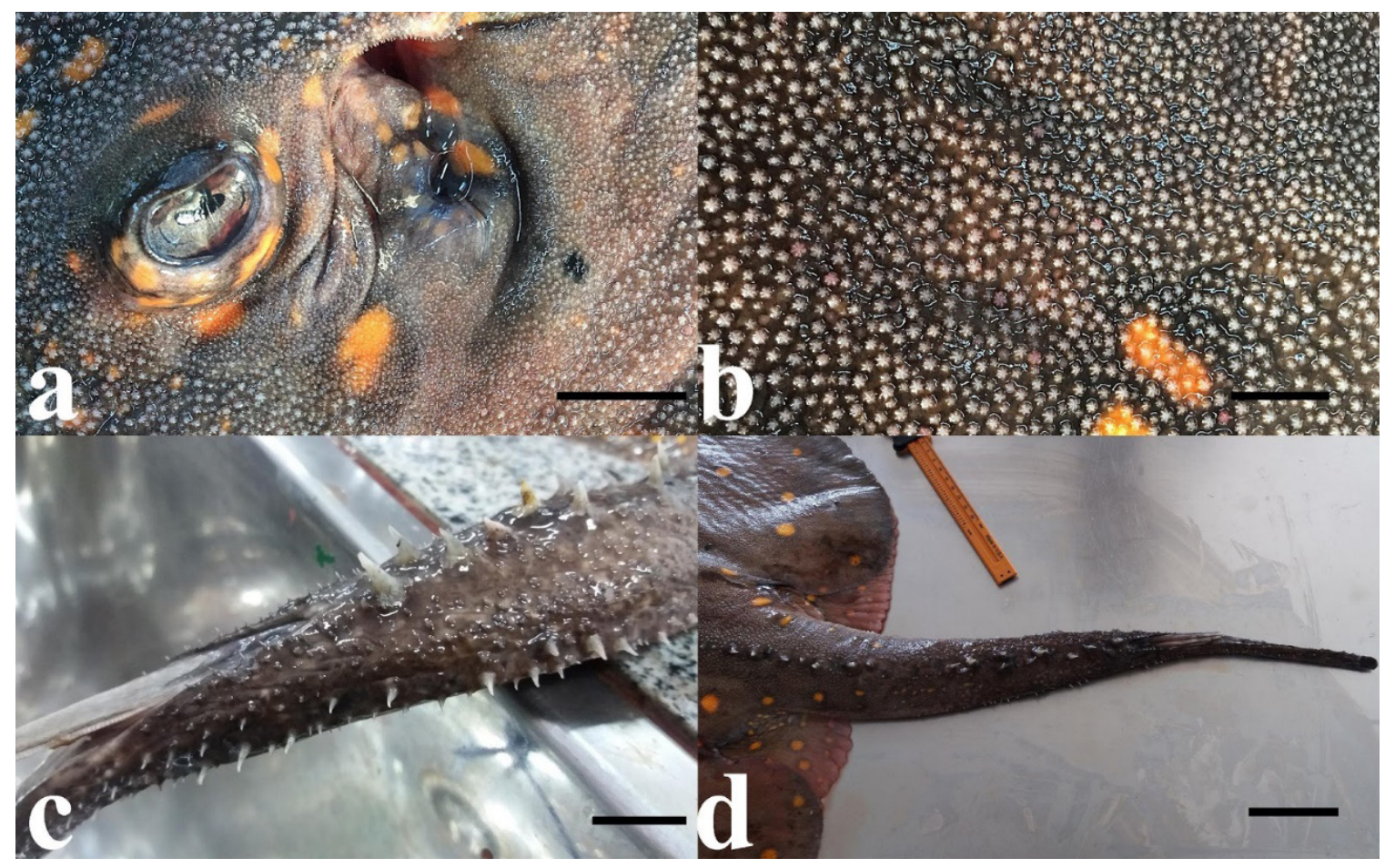

Figure 4. Spinulation on female specimens of $P$. motoro of the Viana Lake. View on the eye-spiracle region (a) and enlargement of the star-shaped denticle type (b). Dorsal and lateral caudal spines on the tail (c, d). Scale bars are: a $-15 \mathrm{~mm}, \mathrm{~b}-5 \mathrm{~mm}, \mathrm{c}-10 \mathrm{~mm}, \mathrm{~d}-$ $40 \mathrm{~mm}$.

\section{Color Pattern}

Disc dorsally olive-brown or dark brown to dark grayish-brown, covered with yellow to orange ocelli, sometimes tricolored ocelli, surrounded by a blackish ring; two or three concentric circles of ocelli progressively enlarging from external to inner ones (Figure 5). Eyes may be surrounded by two or three pairs of small ocelli; 
usually one pair medially anterior, one pair over and one pair posterior to the eyes, but these ocelli may be distributed on the lower surface of the eyes. Spiracles do not show the same surrounding pattern as eyes, but the spiracular valve have one or two pairs of small ocelli extending to the border of spiracles. Larger specimens, specially females, present a randomly distribution of proportionally smaller ocelli eye diameter ocelli - in a spaced pattern, frequently split in two or three small ocelli and a less conspicuous to indistinct blackish ring. Ocelli restricted to the base of the tail, not extending the posterior margin of pelvic fins. Tail with the same background color of the disc, sometimes with scattered small yellowish spots along the sides splitting and waning before the sting base line, where they disappear. Pelvic fins have a faded version of disc color pattern.

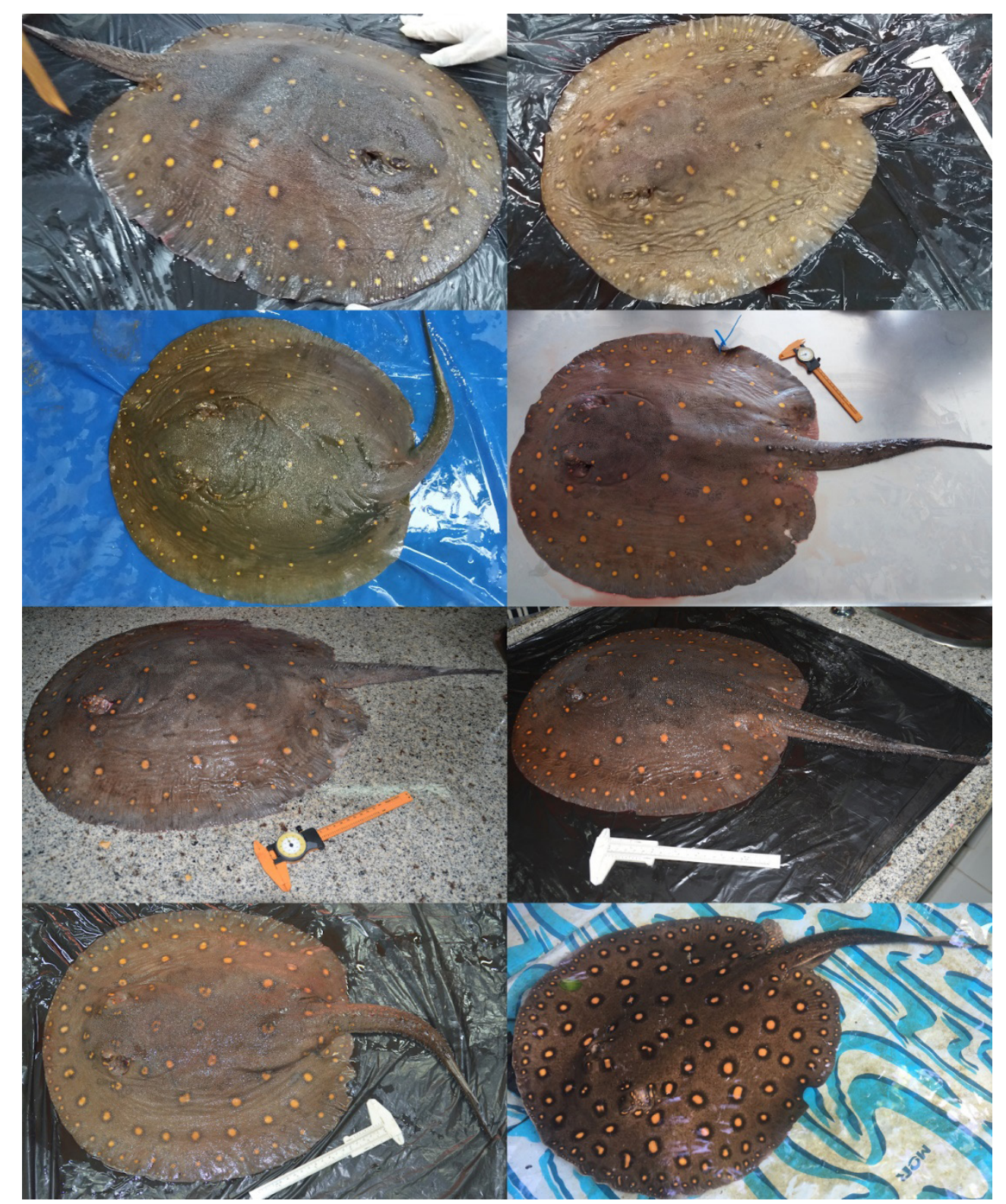

Figure 5. Variation in dorsal color pattern in P. motoro of the Viana Lake. All specimens were recently captured or recently defrozen. Vernier caliper is $150 \mathrm{~mm}$. 
Ventral color is centered white with enlarging and darkening grayish margins from the snout to the pelvic fins, and posteriorly to the cloaca (Figure 6). Scattered darker spots from the margin to the whitish ventral area may occur in both sexes. One recurrent central and irregularly bordered dark spot can be seen over the pectoral girdle. Tail, claspers and posterior margin of pelvic fins are dark gray with scattered whitish spots distributed mostly on the tail.

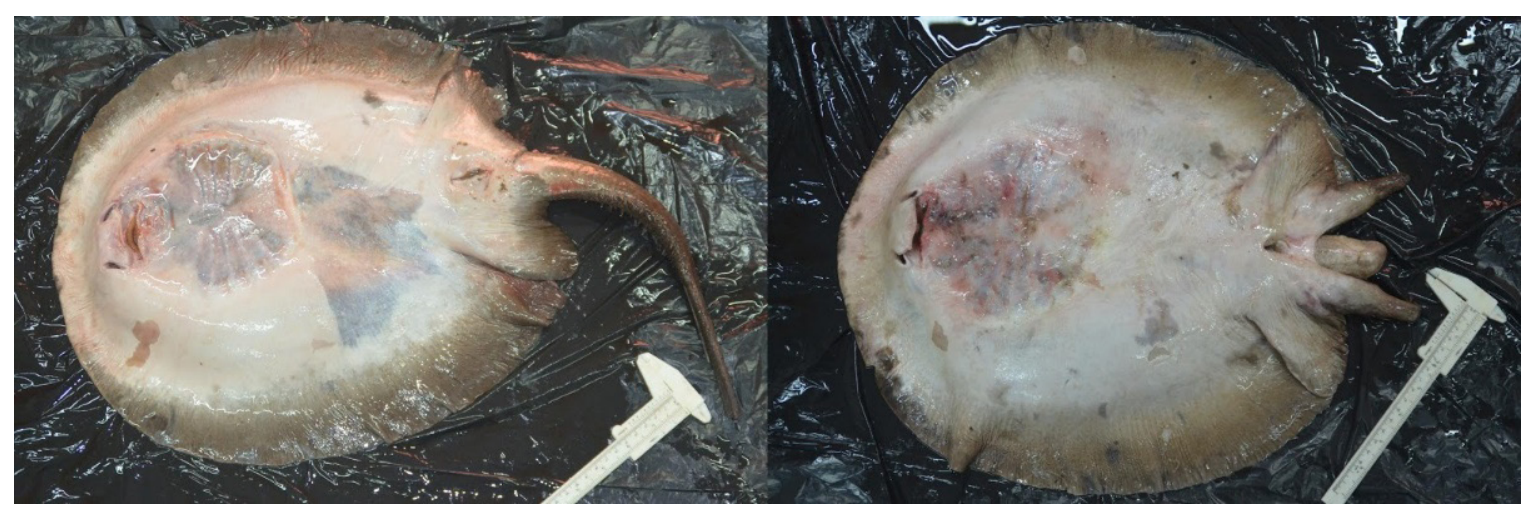

Figure 6. Variation in ventral color pattern in P. motoro of the Viana Lake. Both specimens (female on the left and male on the right) were recently defrozen. Vernier caliper is $150 \mathrm{~mm}$.

\section{Morphometry and Sexual Dimorphism}

Both tests (Student's T-test and Wilcoxon) revealed gender differences in weight and in five body regions (Disc, Head, Tail, Pelvics and Teeth), totaling 16 measurements. In general, it can be said that females have higher mean values of weight and measurements concerning the disc, pelvic and teeth; while males had higher means for head and tail measurements (Table 1). Males presented a head about $10 \%$ larger than females and a longer tail of about $6.5 \%$. However, females had nearly $11.5 \%$ more teeth in the upper jaw than males.

The identified allometric relationships are predominantly negative (Table 2 ), except for the total length in males and the sting length in females, both positive. Males have longer tail lengths than females, as evidenced by the Wilcoxon test. Thus, it is likely that this difference was reflected in the total length, reversing the allometric trend observed in females for a positive allometry in males. 
Table 1. Comparative morphometry of Potamotrygon motoro from Viana Lake for males and females presented for region of the body. Mean values in bold identify the gender with the highest means for each measurement. Means and standard deviations (SD) were estimated on expressions of the percentage of disc width. Student's t-test (T) or Wilcoxon test $(\mathrm{W})$ are presented along with its respective probability $(\mathrm{P})$, number of specimens in the analysis $(\mathrm{N})$ and test result values $(\mathrm{T} / \mathrm{W})$.

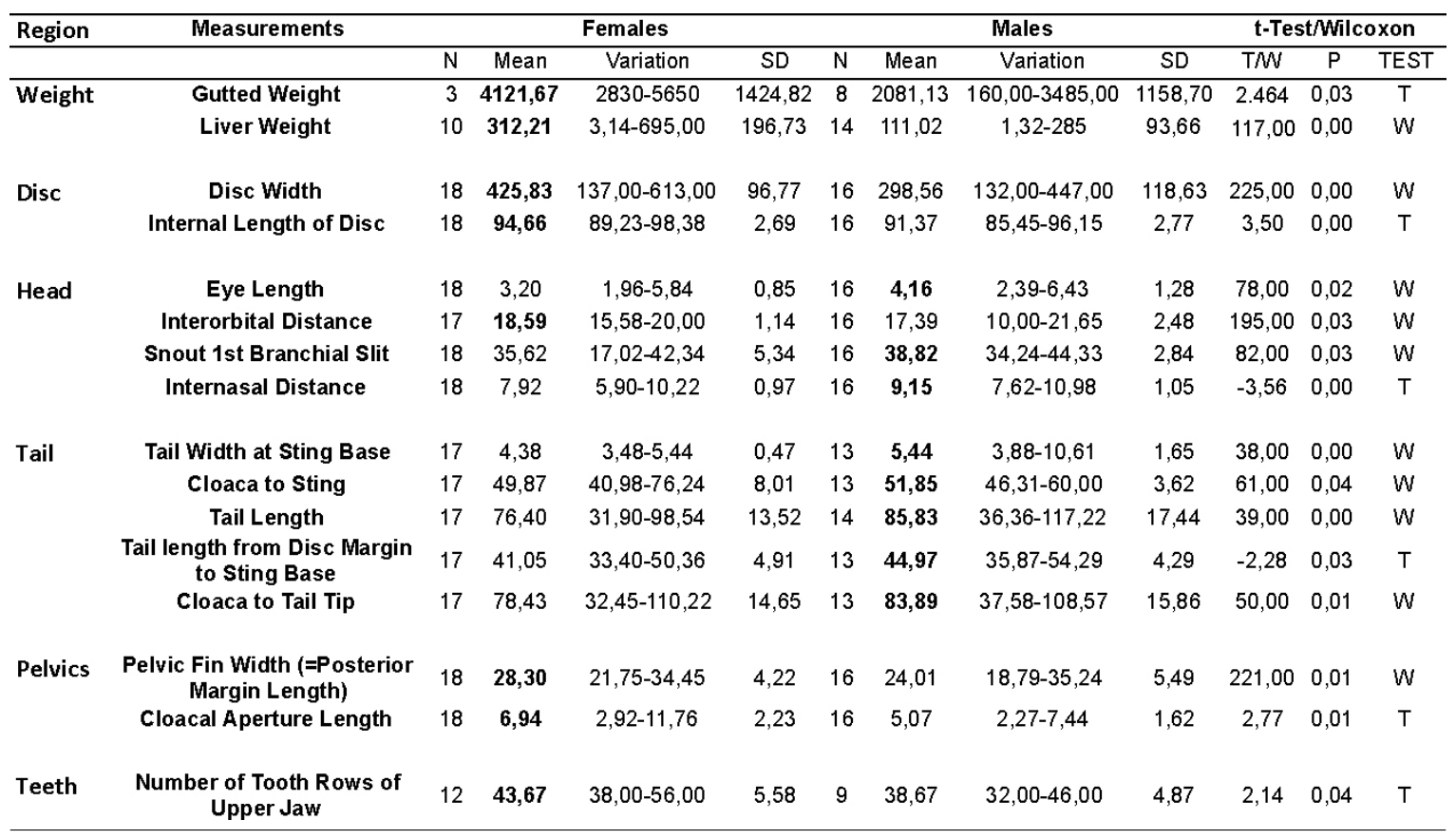


Table 2. Equations resulting from the relationships between linear body dimensions and disc width (DW). The tendency of allometry, positive (+) or negative (-) was expressed for each gender, males (M) and females (F), for total length (TL), disc length (DL), eye length (EL), spiracle length (ESL), sting length (SL), branchial basket length (BBL) and mouth length (MW). The coefficient of determination $\left(r^{2}\right)$ for the linear equations are also represented.

\begin{tabular}{|c|c|c|c|c|}
\hline Measurement & Gender & $\mathbf{N}$ & $\begin{array}{l}\text { Linearized Equation } \\
\log Y=\log a+b \log x\end{array}$ & $\mathrm{r}^{2}$ \\
\hline $\mathrm{TL}$ & $\bar{F}$ & 18 & $\log D W=2,3151+-0,0275 \log T L$ & 0,01 \\
\hline & M & 16 & $\log D W=1,5253+1,5253 \log T L$ & 0,03 \\
\hline $\mathrm{DL}$ & $\begin{array}{l}\mathrm{F} \\
\mathrm{M}\end{array}$ & $\begin{array}{l}18 \\
16\end{array}$ & $\begin{array}{c}\log D W=1,9346+0,0386 \log D L \\
\log D W=-0,4996+0,9152 \log D L\end{array}$ & $\begin{array}{l}0,32 \\
0,21\end{array}$ \\
\hline EL & $\begin{array}{l}\mathrm{F} \\
\mathrm{M}\end{array}$ & $\begin{array}{l}18 \\
16\end{array}$ & $\begin{array}{l}\log D W=2,1121+-0,6234 \log E L \\
\log D W=3,7425+-1,2258 \log E L\end{array}$ & $\begin{array}{l}0,74 \\
0,59\end{array}$ \\
\hline ESL & $\begin{array}{l}\mathrm{F} \\
\mathrm{M}\end{array}$ & $\begin{array}{l}18 \\
16\end{array}$ & $\begin{array}{l}\log D W=1,9353+-0,5048 \log E S L \\
\log D W=1,8080+-0,3784 \log E S L\end{array}$ & $\begin{array}{l}0,41 \\
0,03\end{array}$ \\
\hline SL & $\begin{array}{l}\mathrm{F} \\
\mathrm{M}\end{array}$ & $\begin{array}{c}14 \\
8\end{array}$ & $\begin{array}{c}\log D W=-31,8204+15,5259 \log S \\
\log D W=2,2211+-0,3632 \operatorname{logSL}\end{array}$ & $\begin{array}{l}0,94 \\
0,24\end{array}$ \\
\hline BBL & $\begin{array}{l}\mathrm{F} \\
\mathrm{M}\end{array}$ & $\begin{array}{l}18 \\
16\end{array}$ & $\begin{array}{l}\log D W=1,9877+-0,3707 \log B B L \\
\log D W=1,4004+-0,0716 \log B B L\end{array}$ & $\begin{array}{l}0,26 \\
0,02\end{array}$ \\
\hline MW & $\begin{array}{l}\mathrm{F} \\
\mathrm{M}\end{array}$ & $\begin{array}{l}18 \\
16\end{array}$ & $\begin{array}{l}\operatorname{LogDW}=1,6552+-0,2937 \log M L \\
\log D W=1,2181+-0,0575 \log M L\end{array}$ & $\begin{array}{c}0,39 \\
0,003\end{array}$ \\
\hline
\end{tabular}

\section{DISCUSSION}

Freshwater stingrays are informally known to occur in the Pindaré-Mearim basin since the decade of 1980 (Pinto 1987). Rosa (1985) does not mention the presence of $P$. motoro in the Pindaré-Mearim basin in his review of the South American freshwater stingrays, suggesting that the presence of these stingrays was still unknown by that time. On the other hand, the record of the $P$. motoro is frequently credited to Compagno and Cook (1995), although they provide no source for this information, and subsequently recorded by Soares (2005), where the species was identified as $P$. motoro and corroborated by Loboda (2010) and Loboda and Carvalho (2013).

All analyzed specimens showed a general morphology expected in one single species. However, the genus Potamotrygon tends to present a conservative general morphology in relation to disc shape and proportions, position and size of pelvic fins and tail length. Considering teeth morphology, the specimens analyzed in the present study exhibited clear differentiation between sexes and life stages. Such pattern is expected since most of elasmobranchs present niche segregation, in order to avoid 
direct competition (Bigelow and Schroeder 1953). Immature individuals exhibited uniform teeth, evidence of a more simplified diet based on insect larvae and other invertebrates (unpublished material). Regarding sexes, differences in dentition were also observed, with females presenting more differentiated and heterogeneous teeth. Greater insertion of teeth in the upper jaw in females is also observed in other species, whereas functional consequences remain unknown (Rangel et al. 2016). Studies show that mature males can present great differentiation in relation to dentition, since changes may occur during the reproductive period (Gutteridge and Bennett 2014; Belleggia et al. 2016; Rangel et al. 2016). Such changes make male dentition more triangular and elongated. It is believed that this occurs to facilitate copulation as males need to bite females for fertilization while swimming. In the case of $P$. motoro, male dentition does differ from females, but are simpler and more homogeneous. This result indicates that teething changes for reproduction may not occur in this species, and further studies of the diet of this population are necessary to clarify if such differences are related to diet segregation.

Dermal denticles are associated with reduced drag effect and increasing hydrodynamics (Lang et al. 2012). In addition to species-specific variations, spacing and different shape patterns of dermal denticles are common in the same individual (Loboda and Carvalho 2013; Orlando et al. 2015). These dermal denticles' variations may be associated with the active control of the external margin of the pectoral fin, a characteristic that aids on movement as well as swimming speed (Blevins and Lauder 2012). That is, changes in the frequencies of pectoral fins beats assist in animal's movement, and the presence of smaller and multicuspid dermal denticles may be associated with the various swimming functions performed by the margins of these fins, reducing the need for hydrodynamic dermal specialization to reduce water drag.

One of the main defense structures of freshwater stingrays is the caudal sting and its serrated anatomy aids in poison's penetration (Naylor et al. 2016). The spines in the dorsal and lateral region of $P$. motoro tail may also be an anti-predatory advantage. When benthic rays detect a threat, tail-side (horizontal or vertical) movements are employed to ward off the predator using the stinger as a primary weapon (Hughes et al. 2018). In situations where the predator is not hit by the caudal sting, spines in the dorsal and ventral tail will increase the likelihood of predator's injuring, an additional defense mechanism against threats. Further studies on $P$. motoro behavior are necessary to better understand the role of caudal spines in defense.

Loboda (2010) analyzed one female specimen captured in the Pindaré-Mearim basin (MZUSP-51676 mature female, $285 \mathrm{~mm}$ DW) collected by Paulo E. Vanzolini in 1955. He provides a morphometric description of this specimen along with its color identification and dermal denticles grouping and a geographic analysis of its possible interrelationships in the Amazon basin. This author concludes that the color pattern presented by the Pindaré-Mearim specimens is closely related to the color pattern presented by specimens in the Marajó Island. The color variation observed in the 
present analysis seems to be related to growth, where large specimens present ocelli relatively smaller and more spaced than smaller specimens. Similar pattern was observed in P. scobina by Almeida (2003) in specimens from the Marajó bay, where a series of different color patterns were described. However, the same author concluded that all different color patterns belonged to the same species based on mitochondrial DNA (16 S) gene analysis. Immediately after capture, all specimens showed very similar background color pattern. The dorsal background color variation observed between specimens in Figure 5 may be related to profound stress before death and/or previous fight against the hook and line, deeply scratching the dorsal surface into a hematoma condition. The same pattern was also observed in the ventral color, where some specimens showed a reddish color probably related to abrasion or pressure against a rough surface. This is more concerning when the animal is preserved for a medium to long time, since it gives a shady cream where originally it was cream and a faded gray where it was dark gray.

In the present study, morphometric differences were observed when comparing males and females. Considering the eviscerated weight and liver weight, females presented higher values. This pattern is expected, since adult females have developed reproductive system that weighs more than the male reproductive tract, adding more volume to the total viscera weight. The difference observed in liver weight is also expected, since adult females require greater energy mobility and organ functioning for vitellogenesis and nutrition during the period of embryonic development (Conrath and Musick 2012).

External morphological differences between males and females are not uncommon in elasmobranchs. In general, females are larger, given the need for maternal investment during embryonic development (Walker 2005). In some species, fertility is directly related to body size, with the larger and older females generating more offspring (Walker 2005). In the present study, females presented larger disc width. This pattern may correspond to evolutionary adaptations related to viviparity, in which larger internal space is necessary to promote greater womb accommodation for the litter (Martins et al. 2015). Still, considering reproductive aspects, females presented longer cloaca length compared to males, a pattern expected, since this structure has additional functions in females (Conrath and Musick 2012). As elasmobranchs copulate while swimming, increasing cloaca length in females facilitate clasper insertion, as well as birth.

Another variation observed was in the width of the pelvic fins, being larger in females than males, a difference that may be essential in reproductive behavior, such as copulation, as observed for some shark species (Martins et al. 2015). The hydrodynamic contribution of the pelvic fin should also be considered, as it plays an important mechanical function (Raff 2012). Briefly, the pelvic fins compensate for the rippling of the pectoral fins by propelling the body against the substrate, performing synchronized ambipedal maneuvers and prey capture movements (Shibuya et al. 2015). Thus, it is possible that the increase in pelvic fin width in females may occur 
due to the need to optimize swimming movements as a way to compensate for the larger dimensions of its disc (Macesic et al. 2013).

The longest tail length and largest tail width in males may be related to the evolutionary adaptation observed in males in some elasmobranchs. More specifically, males tend to have a more hydrodynamic and fusiform body, indicating niche sexual segregation (Piorski and Nunes 2000) and swimming dynamics adaptations necessary for the active pursuit of females (Rolim et al. 2015). The tail in freshwater stingrays does not seem to have as many functions explored in swimming as for defense (Macesic et al. 2013), but we believe that the longer tail length presented by the males in the present study may contribute to a more hydrodynamic swimming activity (Lauder and DiSanto 2015). Finally, the greater tail width in the thorn insertion region may be related to defense and/or competition behaviors. Behavioral studies conducted with the captive $P$. motoro indicate that the court is extremely complex, with some bites and other same-sex agonistic behaviors, probably linked to competition for partners (Wren and Fletcher 2001). However, further studies are needed to elucidate the relationship between greater muscle development in the region and agonistic behaviors.

\section{CONCLUSION}

Here we present unpublished data on morphology and morphometry genderbased in P. motoro caught in the Pindaré-Mearim river basin. These data are important so that future comparisons with individuals of this species captured in other regions can be made.

\section{ACKNOWLEDGEMENTS}

Authors would like to thank the fishermen who helped capture the animals.

\section{REFERENCES}

A breu JMS, Craig JM, Albert JS, Piorski, NM. 2019. Historical biogeography of fishes from coastal basins of Maranhão State, northeastern Brazil. Neotropical Ichthyology, 17(2), e180156. https://dx.doi.org/10.159o/1982-0224-20180156

Almeida MP. 2003. Pesca, Policromatismo e Aspectos Sistemáticos de Potamotrygon scobina (Chondrichthyes: Potamotrygonidae) da Região da Ilha de Colares - Baía de Marajó - Pará. Master Thesis. Universidade Federal do Pará \& Museu Paraense Emílio Goeldi, Belém, 145 p. 
Almeida MP, Barthem RB, Viana AS, Almeida PC. 2008. Diversidade de raias de água doce (Chondrichthyes: Potamotrygonidae) no estuário amazônico. Arquivos de Ciências do Mar, 41(2): 82-89. https://doi.org/10.3236o/acmar.v41i2.6067

Belleggia M, Andrada N, Paglieri S, Cortés F, Massa AM, Figueroa DE, Bremec C. 2016. Trophic ecology of yellownose skate Zearaja chilensis, a top predator in the south-western Atlantic Ocean. Journal of Fish Biology, 88:1070-1087. https://doi. org/10.1111/jfb.12878

Bigelow HB, Schroeder WC. 1951. The Fishes of the Western North Atlantic, Part I. Sawfishes, Guitarfishes, Skates and Rays, Chimaeroids. New Heaven: Yale University Press, 576 p.

Bigelow HB, Schroeder WC. 1953. The Fishes of the Western North Atlantic, Part II. Sawfishes, Guitarfishes, Skates and Rays, Chimaeroids. New Heaven: Yale University Press, 558 p. doi: 10.2307/j.ctvbcdof3

Blevins EL, Lauder GV. 2012. Rajiform locomotion: three-dimensional kinematics of the pectoral fin surface during swimming in the freshwater stingray Potamotrygon orbignyi. Journal of Experimental Biology, 215(18), 3231-324. doi:10.1242/jeb.o68981

Carvalho M, Lovejoy NR, Rosa RS. 2003. Family Potamotrygonidae. In: Reis RE et al. (Eds), Checklist of the Freshwater Fishes of South and Central America, Porto Alegre: Edipucrs, 742 p.

Carvalho MR. 2016. Neotropical Stingrays, Family Potamotrygonidae. In: Last P et al. (Eds.) Rays of the World. Csiro Publishing p. 619-655.

Castro-Aguirre JL. 1978. Catálogo sistemático de los peces marinos que penetran a las aguas continentales de México,con aspectos zoogeográficos y ecológicos. Departamento de Pesca, México, Serie Científica 19: XI + 298 p.

Cervigón F, Cipriani R, Fisher W, Garibaldi L, Hendrickx M, Lemus AJ, Márquez R, Poutiers JM, Robaina G, Rodriguez B. 1992. Fichas FAO de identificación de especies para los fines de la pesca: guía de campo de las especies comerciales marinas y de aquas salobres de la costa septentrional de Sur América. Rome: FAO, 523 p.

Charvet-Almeida P. 2001. Ocorrência, biologia e uso das raias de água doce na Baía de Marajó (Pará, Brasil), com ênfase na biologia de Plesiotrygon iwamae (Chondrichthyes : Potamotrygonidae). Universidade Federal do Pará e Museu Paraense Emílio Goeldi, Programa de Pós-Graduação em Zoologia, 213 p. 
Compagno LJV, Cook SF. 1995. The exploitation and conservation of freshwater elasmobranchs: Status of taxa and prospects for the future. Journal of Aquaculture and Aquatic Sciences, 7, 62-90.

Conrath, CL, Musick, JA. 2012. Reproductive biology of elasmobranchs. In: Carrier JC et al. (Eds.). Sharks and Their Relatives, Vol.II. Boca Raton: CRC Press p. 291-312. doi: 10.1201/b11867-13

Deynat PP, Séret B. 1996. Le revêment cutané des raies (Chondrichthyes, Elasmobranchii, Batoidea). I: Morphologie et arrangement des denticules cutanés. Annales des Sciences Naturalles, Zoologie, 17: 65-83.

Feitosa LM, Martins APB, Nunes, JLS. 2016. New record of Carcharhinus leucas (Valenciennes, 1839) in an equatorial river system. Marine Biodiversity Records, 9:(1). doi:10.1186/s41200-016-0094-6

Feitosa LM, Martins APB, Nunes JLS. 2017. Sawfish (Pristidae) records along the Eastern Amazon coast. Endangered Species Research, 34: 229-234. https://doi. org/10.3354/esroo852

Feitosa LM, Martins APB, Giarrizzo T, Macedo W, Monteiro ILP, Gemaque R, Nunes JLS, Gomes F, Schneider H, Sampaio I, Souza RFC, Sales JBL, Rodrigues-Filho LFS, Tchaika L, Carvalho-Costa LF. 2018. DNA-based identification reveals illegal trade of threatened shark species in a global elasmobranch conservation hotspot. Scientific Reports, 8, 1-11. https://doi.org/10.1038/s41598-018-21683-5

Geyer WR, Beardsley RC, Lentz SJ, Candela J, Limeburner R, Johns WE, Castro BM, Soares ID. 1996. Physical oceanography of the Amazon shelf. Continental Shelf Research 16: 575-616.

Gutteridge AN, Bennett MB. 2014. Functional implications of ontogenetically and sexually dimorphic dentition in the eastern shovelnose ray, Aptychotrema rostrata. Journal of Experimental Biology, 217:192-200. doi: 10.1242/jeb.089326

Hughes R, Pedersen K, Huskey S. 2018. The kinematics of envenomation by the yellow stingray, Urobatis jamaicensis. Zoomorphology, 137(3), 409-418. https://doi. org/10.1007/s00435-018-0404-o

Lang, A, Habegger ML, Motta P. 2012. Shark skin drag reduction. Encyclopedia of Nanotechnology, 2394-2400. https://doi.org/10.1007/978-90-481-9751-4_266 
Lauder, GV, Di Santo, V. 2015. Swimming Mechanics and Energetics of Elasmobranch Fishes. In: Shadwick RE et al. (Orgs) Fish Physiology, Physiology of Elasmobranch Fishes: Structure and Interaction with the Environment, London: Eselvier, p. 219-253.

Loboda, T. S. 2010. Revisão taxonômica e morfológica de Potamotrygon motoro (Müller \& Henle, 1841) na bacia Amazônica (Chondrichthyes: Myliobatiformes: Potamotrygonidae). Instituto de Biociências da Universidade de São Paulo, 305 p.

Loboda TS, Carvalho MR. 2013. Systematic revision of the Potamotrygon motoro (Müller \& Henle, 1841) species complex in the Paraná-Paraguay basin, with descriptions of two new ocellated species (Chondrichthyes: Myliobatiformes: Potamotrygonidae). Neotropical Ichthyology, 11(4): 693-737. http://dx.doi.org/10.1590/S1679$\underline{62252013000400001}$

Macesic LJ, Mulvaney D, Blevins EL. 2013. Synchronized swimming: coordination of pelvic and pectoral fins during augmented punting by the freshwater stingray Potamotrygon orbignyi. Zoology, 116(3): 144-150. doi:10.1016/j.zool.2012.11.002

Martins APB, Silva-Filho E, Feitosa LM, Nunes e Silva LP, Almeida ZS, Nunes JLS. 2015. Sexual dimorphism of sharks from the amazonian equatorial coast. Universitas Scientiarum, 20(3): 297-304. doi:10.11144/javeriana.sc20-3.sdos

Naylor GJP, Yang L, Corrigan S, Carvalho, MD. 2016. Phylogeny and classification of rays. In: Last P et al. (Eds) Rays of the World. Clayton South (AU): CSIRO Publishing, p. 10-15.

Nittrouer CA, DeMaster DJ. 1996. The Amazon shelf setting: tropical, energetic, and influenced by a large river. Continental Shelf Research 16: 553-574.

Orlando P, González-Castro M, Mabragaña E. 2015. New insights to discriminate between Sympterygia acuta Garman 1877 and Sympterygia bonapartii Müller \& Henle, 1841 (Rajidae) of the Southwest Atlantic Ocean: on the use of geometric morphometrics and spinulation patterns. Journal of Applied Ichthyology, 31(2), 381-389. https:// doi.org/10.1111/jai.12674

Pereira LCC, Silva NIS, Costa RM, ASP NE, Costa KG, Vila-Concejo A. 2012. Seasonal changes in oceanographic processes at an equatorial macrotidal beach in northern Brazil. Continental Shelf Research, 43: 95-106. https://doi.org/ 10.1016/j. csr.2012.05.003

Pezzuto PR. 1993. REGRANS: a "BASIC" program for an extensive analysis of relative growth. Atlântica, 15: 93-105. 
Pinto JA. 1987. Biologia de Potamotrygon motoro (Pisces: Rajiformes) do complexo lagunar de Viana-Maranhão. Universidade Federal do Maranhão, Centro de Ciências da Saúde, 45p.

Piorski NM, Nunes JLS. 200o. Dimorfismo sexual e tendência alométrica de Urotrygon microphtalmum Delsman, 1941 (Elasmobranchii: Urolophidae). Boletim do laboratório de Hidrobiología, 13(1): 67-81.

Piorski, NP, Ferreira, B.R.A, Guimarães, EC, Ottoni, FP, Nunes, JLS, Brito, PS. 2017. Peixes do Parque Nacional dos Lençóis Maranhenses. São Luís: EDUFMA/Café \& Lápis, 189 p.

R Development Core Team. 2011. R: A Language and Environment for Statistical Computing. The R Foundation for Statistical Computing, Vienna, Austria. http:// www.R-project.org/

Raff RA. 2012. The Shape of Life: Genes, Development, and the Evolution of Animal Form. Chivago: University of Chicago Press, 544 p.

Rangel BS, Santander-Neto J, Rici RE, Lessa R. Dental sexual dimorphism and morphology of Urotrygon microphthalmum. 2016. Zoomorphology, 135(3): 367-74. doi:10.1007/s00435-016-0312-0

Rolim F, Caltabellotta F, Rotundo M, Vaske-Júnior T. 2015. Sexual dimorphism based on body proportions and ontogenetic changes in the Brazilian electric ray Narcine brasiliensis (von Olfers, 1831) (Chondrichthyes: Narcinidae). African Journal of Marine Science, 37(2), 167-176. doi:10.2989/1814232X.2015.1032350

Rosa RS. 1985. A systematic revision of the South American freshwater stingrays (Chondrichthyes: Potamotrygonidae). Dissertation for the degree of doctor of philosophy, Faculty of the School of Marine Science, College of William and Mary Virginia, $523 \mathrm{p}$.

Rosa RS, Carvalho, MR. 2016. Claves para la identificación de las rayas de agua dulce (Potamotrygonidae). In: Lasso CA et al (Eds.) XV. Rayas de agua dulce (Potamotrygonidae) de Suramérica. Parte II: Colombia, Brasil, Perú, Bolivia, Paraguay, Uruguay y Argentina. Serie Editorial Recursos Hidrobiológicos y Pesqueros Continentales de Colombia. Bogotá: Instituto de Investigación de Recursos Biológicos Alexander von Humboldt (IAvH), p. 104-126.

Silva JPCB DA, Loboda TS. 2019. Potamotrygon marquesi, a new species of neotropical freshwater stingray (Potamotrygonidae) from the Brazilian Amazon Basin. Journal of Fish Biology. 2019; 95: 594- 612. https://doi.org/10.1111/jfb.14050 
Soares EC. 2005. Peixes do Mearim. São Luis: Editora Instituto Geia. 412 p.

Shibuya A, Carvalho MR, Zuanon J, Sho T. 2015. The use of pelvic fins for benthic locomotion during foraging behavior in Potamotrygon motoro (Chondrichthyes: Potamotrygonidae). Zoologia, 32(3): 179-186. http://dx.doi.org/10.1590/S198446702015000300001

Thorson TB. 1983. Observations on the morphology, ecology and life history of the euryhaline stingray, Dasyatis guttata (Bloch \& Schneider, 1801). Acta Biologica Venezuelica, 11(4): 95-125.

Walker TI. 2005. Reproduction in Fisheries Science.. In: Hamlett WC (Ed). Reproductive Biology and Phylogeny of Chondrichthyes: Sharks, Batoids and Chimaeras. Enfield, New Hampshire: Science Publishers Inc, p. 82-127.

Wren S, Fletcher A. 2001. Investigation of behavioural interaction within freshwater stingrays (Potamotrygon motoro) at Chester Zoo. In: Proceedings of the zrd Annual Symposium on Zoo Research, Chester, UK: The North of England Zoological Society, p 173-183 